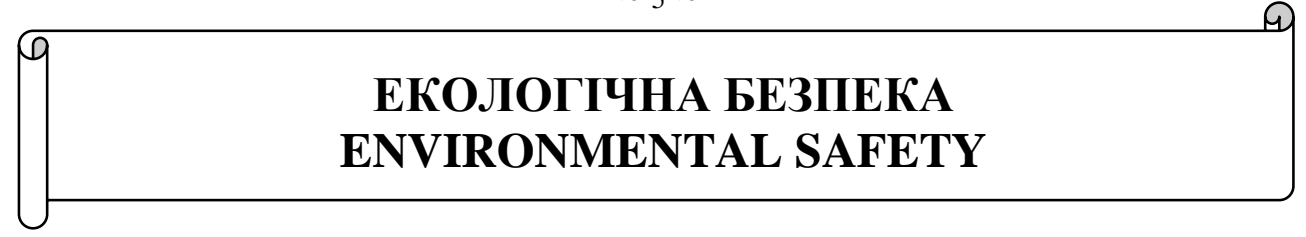

UDK (550.4:550.42):628.542](477)

Oleksandr M. Trofymchuk ${ }^{1}$, D. S. (Engineering), Professor, Corresponding Member of NASU, Director

ORCID ID 0000-0003-3782-4209 e-mail: itelua@kv.ukrtel.net

Iryna V. Kuraeva ${ }^{2}$, D. S. (Geology), Professor, Head of Department

ORCID ID 0000-0003-3113-7782 e-mail: ki4412674@gmail.com

Oleksandr T. Azimov ${ }^{3}$, D. S. (Geology), Leading Researcher

ORCID ID 0000-0002-5210-3920 e-mail: azimov@ casre.kiev.ua

Sergii P. Karmazinenko ${ }^{4}, \mathrm{PhD}$, Senior Researcher

ORCID ID 0000-0001-8268-7851 e-mail: karmazinenko78@gmail.com

Kateryna S. Zlobina ${ }^{2}, \mathrm{PhD}$, Junior Researcher

ORCID ID 0000-0001-8823-4642 e-mail: ecaterinka@ukr.net

${ }^{1}$ Institute of Telecommunications and Global Information Space of NASU, Kyiv, Ukraine

${ }^{2}$ M.P. Semenenko Institute of Geochemistry, Mineralogy and Ore Formation of NASU, Kyiv, Ukraine

${ }^{3}$ Scientific Centre for Aerospace Research of the Earth of IGS of NASU, Kyiv, Ukraine

${ }^{4}$ Institute of Geography of NASU, Kyiv, Ukraine

\title{
GEOCHEMICAL CHARACTERISTICS FOR THE SOIL DEPOSITS WITHIN THE MUNICIPAL WASTE DISPOSAL AREAS BY THE ENVIRONMENT STUDY RESULTS
}

\begin{abstract}
As a result of the analytical research and result of the previous stages of study it was found the significant contamination of the soil layer by the heavy metals (HMs) within the Landfill area No 5 for the municipal solid waste (MSW) disposal and the surrounding areas. It was revealed also the negative its effect on the contents of these pollutants in the soil of adjacent buffer zone, which is under the influence of north-eastern, northern, and north-western parts of the Landfill. This is a result of 34 years of the operation of the MSW disposal facility, when there were operating troubles. That caused by the breach of operating procedures of the covering the garbage storages by the isolating layers of dirt, intermittent work of the leachate treatment system, capacity exceeded, etc. Therefore, the soils within the Landfill's boundaries and also in the buffer its zone have been contaminated by the different toxic substances, in particular by the HMs. So, soil deposits of the Landfill have got the maximum exceed of background contents for cooper, lead, nickel, and tin by from several to ten times, at the same time, beyond its contour - by 2-3 times.
\end{abstract}

(C) О.М. Трофимчук, І.В. Кураєва, О.Т. Азімов, С.П. Кармазиненко, К.С. Злобіна, 2020

ISSN: 2411-4049. Екологічна безпека та природокористування, № 3 (35), 2020 
The negative changes of physical-chemical properties of soils of the humus horizon is revealed by the comparison with the proper indications for the soil samples collected in the sites adjacent to the Landfill and directly on its territory. The buffer coefficient of soil of this horizon $\left(C_{b}\right)$ is twice as lower for the technogenic polluted soils within the MSW disposal facility than for the background sites for their is equal to the value of $C_{b}=55$. The contents of mobile forms for the HMs in the soil formations of the Landfill No 5 in the comparison with the background values increase 2 times for cooper and zinc, as well 8 times for lead. It is the content of the mobile forms that affects the migration of the HMs in the trophic chain "soil - solution - biota".

Keywords: Landfill; solid waste; heavy metals; soil; geochemical analysis

\author{
О.М. Трофимчук ${ }^{1}$, І.В. Кураєва ${ }^{2}$, О.Т. Азімов ${ }^{3}$, С.П. Кармазиненко ${ }^{4}$, К.С. Злобіна ${ }^{2}$ \\ ${ }^{1}$ Інститут телекомунікацій і глобального інформаційного простору НАН України, \\ м. Київ, Україна \\ ${ }^{2}$ Інститут геохімії, мінералогії та рудоутворення імені М.П. Семененка НАН України, \\ м. Київ, Україна \\ ${ }^{3}$ Науковий центр аерокосмічних досліджень Землі ІГН НАН України, м. Київ, Україна \\ ${ }^{4}$ Інститут географії НАН України, м. Київ, Україна
}

\title{
ГЕОХІМІЧНІ ХАРАКТЕРИСТИКИ ГРУНТОВИХ УТВОРЕНЬ РАЙОНІВ ЗАХОРОНЕННЯ ПОБУТОВИХ ВІДХОДІВ ЗА РЕЗУЛЬТАТАМИ ЕКОЛОГІЧНИХ ДОСЛІДЖЕНЬ
}

\begin{abstract}
Анотація. Викладено результати аналітичного узагальнення матеріалів новітніх $i$ попередніх етапів досліджень геохімічних особливостей проб трунтових відкладів по території Київського полігона № 5 захоронення твердих побутових відходів (ТПВ) та у прилеглих до неї районах. Встановлено істотне забруднення трунтового шару важкими металами (BM), передусім у межах полігона. Виявлено також негативний його вплив на вміст изих полютантів у трунтах буферної, прилеглої до полігона зони, щчо, імовірно, зазнає впливу північно-східної, північної та північно-західної його частин. Це стало наслідком 34-річного функиіонування об'єкта захоронення ТВП, протягом якого мали місие порушення в його експлуатації. Вони були зумовлені недотриманням технології пересипки складованих відходів ізоляційним шаром землі, нерегулярною роботою установки з переробки фільтрату, перевищенням потужностей тощо. Отож трунти в межах полігона $i$ навіть у буферній до нього зоні зазнали забруднення різноманітними токсичними речовинами, зокрема, ВМ. Зокрема, для трунтових утворень полігона визначено максимальне перевищення фонового вмісту міді, свинию, иинку, нікелю та олова у десятки разів, у той же час поза його контуром - у 2-3 рази. Зафіксовані негативні зміни фізико-хімічних властивостей трунтів гумусового горизонту при порівнянні відповідних показників за зразками, відібраними у прилеглих до полігона районах $i$ безпосередньо на його території. Коефіцієнт буферності трунтів иъього горизонту $\left(K_{б}\right)$ майже вдвічі менший на техногенно забруднених землях об'єкта захоронення ТВП, ніж на відносно фонових ділянках, для яких одержано значення $K_{\sigma}=55$. Вміст рухомих форм ВМ у трунтових утвореннях полігона № 5 порівняно з фоновими значеннями зростає у 2 рази для міді та ичинку, а для свинцю - у 8 разів. Саме вміст рухомих форм здійснює вплив на міграцію ВМ у трофічному ланцюгу «трунт - розчин - біота».
\end{abstract}

Ключові слова: полігон; побутові відходи; важскі метали; трунт; геохімічний аналіз 


\section{Формування цілей і завдань статті}

В Україні (без урахування даних Автономної республіки Крим та м. Севастополь) за 2019 р. утворено майже 53 млн м³ побутових відходів, або понад 10 млн т [1]. Переважна частка 3 них захоронювалася на 6 тис. сміттєзвалищ і полігонів загальною площею понад 9 тис. га. При цьому кількість перевантажених сміттєзвалищ становить 258 одиниць (4,2\%), а 905 од. (15\%) не відповідають санітарно-гігієнічним нормам та нормам екологічної безпеки. Більшість полігонів не мають інженерно-геологічних обгрунтувань.

Зазначене призводить до того, що у межах як власне полігонів, так і у прилеглих до них районах значних техногенних змін зазнають грунтові відклади, поверхневі води, грунтові води неглибокого залягання, а також часто докорінно змінюються рослинні угруповання [2-24 та ін.].

Фізико-хімічні процеси забруднення життєво важливих для людини об'єктів довкілля на таких територіях вивчені не повною мірою. При цьому грунтові утворення $€$ найбільш важливим біокосним депонуючим середовищем [25]. Важливу роль у фізіологічних, біо- та геохімічних процесах, що протікають у грунтах, відіграють важкі метали (ВМ). Вони визначають оптимальні умови існування живих організмів у грунті та його біологічну продуктивність.

Таким чином, у цій статті на підставі результатів опрацювання відібраних проб розглянемо узагальнені дані щодо геохімічних характеристик грунтових відкладів, які є об'єктом досліджень, у районі одного з найбільших в Україні полігонів захоронення твердих побутових відходів (ТПВ). Предметом досліджень при цьому є особливості геохімії ВМ у грунтових утвореннях.

Фактичний матеріал для аналізу отриманий нами як у червні 2019 р. $[18,19,24]$, так і протягом робіт попереднього року [11-17, 20, 23, 24 та ін.] по декількох площадках спостережень безпосередньо поблизу карти складування № 1 Киӥвського полігона № 5 захоронення ТПВ та у прилеглих до неї 3 північного сходу та північного заходу районах (рис. 1). Вірогідно, ландшафтні компоненти цих розташованих поза межами полігона буферних стосовно нього районів (або зон) зазнають довготривалого впливу існування і діяльності полігона, ТПВ на якому захоронюються починаючи ще з 1986 року.

Більшість площадок спостережень 2019 року просторово збігається 3 площадками відбору зразків грунтового покриву попередніх років (у цьому $є$ елемент геомоніторингу) або ж своїм розташуванням робить мережу опробування більш детальною. Проте, в узагальнення матеріалу залучені додаткові дані за пробами, відібраними у буферній зоні на північний схід від контуру полігона та на території с. Підгірці, що розляглося на схід від нього.

При цьому головне завдання досліджень передовсім полягає у визначенні максимальних значень різних геохімічних параметрів грунту поміж усіх узагальнених даних по території черги «А» полігона та по буферній до неї зоні. Наступним кроком було аналітичне порівняння їх 3 такими ж характеристиками фонових грунтів, що притаманні регіону, в межах якого розміщений полігон № 5. Як матеріал для порівняння використано викладені у праці [26] результати оцінки особливостей геохімії грунтових горизонтів нашої ландшафтно-кліматичної підзони - лісостепу правобережного високого (переважно) і низького (частково). Першим кроком на цьому шляху було встановлення типів грунтів та їхніх основних характеристик у розрізах 
відслонень (розчистках) під час виконання польових робіт та за виготовленими на підставі відібраних проб спеціальних шліфів.

\section{Характеристика об'єкта досліджень}

Полігон № 5 розташований приблизно в 11 км на південь від житловопромислової забудови південної частини м. Києва. ТПВ складуються в межах колишніх, заповнених ними двох лівих приток (ярів субмеридіонального спрямування) Ходосівської балки урочища Марусин Яр (рис. 1, див. рис. 1 у $[11,15,17,19,23])$. Балка простяглася між с. Підгірці (на відстані 750 м) та с. Креничі (на відстані 500 м).

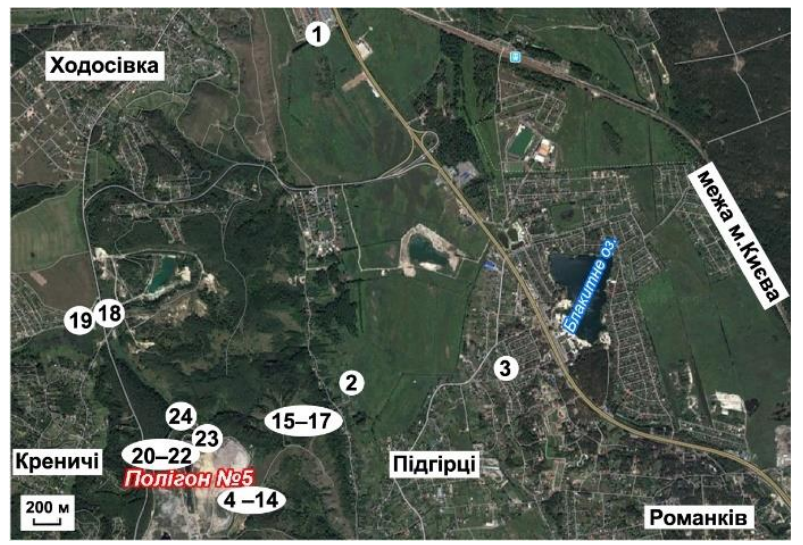

Рис. 1 - Картосхема розташування площадок спостережень (1-24) у північному секторі впливу полігона № 5. Як підкладку використано космічний знімок, отриманий з Інтернет-джерела [27]

Стосовно технічних характеристик полігона № 5 зазначимо, що загальна його площа становить 63,7 га. Він складається 3 двох майданчиків (або черг, карт) складування: карти № 1 (або «А») площею 18 га та карти № 2 (або «Б»), яка має площу 17 га (рис. 2). Полігон щодня приймає від 4000 до 5000 м 3 ТПВ.

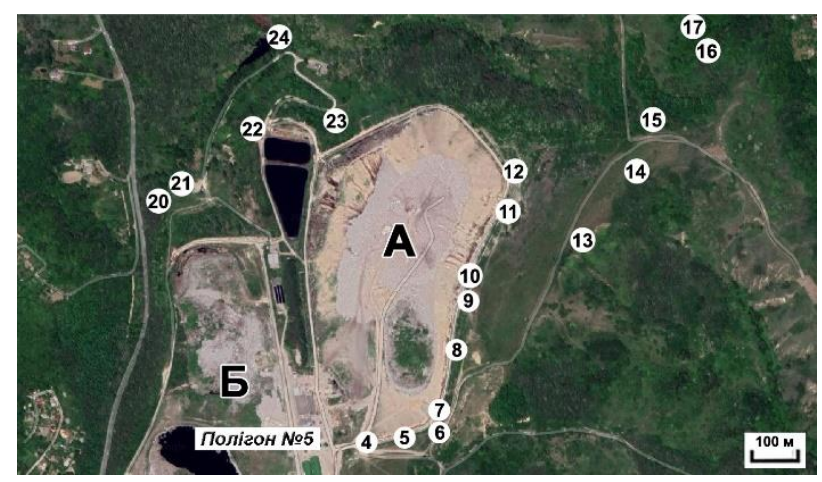

Рис. 2 - Картосхема розташування площадок спостережень у межах північно-західної частини полігона № 5 (20-24) та у буферній стосовно карти «А» зоні (4-17). $A, D$ - карти полігона. Як підкладку використано космічний знімок, отриманий з Інтернет-джерела [27] 
32006 р. йде мова про повне закриття полігона № 5 через порушення в його експлуатації та критичний екологічний стан, насамперед пов'язаний 3 витіканням фільтрату в землю та забруднення ним довкілля, передусім підземних вод. Фільтрат утворюється із стічних вод, що виникають в результаті інфільтрації атмосферних опадів у “тіло” власне звалища сміття, а потім концентруються в його основі. При цьому проходячи через товщу відходів, фільтрат збагачується різноманітними токсичними речовинами, що входять до їх складу, або ж насичується продуктами їх розкладання. Таким чином, утворені водні розчини є хімічно й біологічно активними. А поруч із полігоном протікає річка Віта, яка впадає у Дніпро.

Втім, експлуатація полігона № 5 продовжується дотепер. Послуги 3 захоронення ТПВ на ньому надає підприємство «Приватне акціонерне товариство (ПрАТ) «Київспецтранс», що утилізує понад половину цього типу відходів міста Києва. Тобто на п’ятий полігон припадає “левова” частка сміття, що утворюється внаслідок життєдіяльності населення міста.

\section{Матеріали досліджень}

3 метою оцінки впливу фільтрату, що надходить до геологічного середовища 3 полігона № 5, на стан грунтів, як у межах об’єкта захоронення ТПВ, так і прилеглої до нього території, насамперед були проведені польові дослідження. Вони включали такі види робіт:

- візуальний аналіз гідролого-геоморфологічних особливостей території досліджень;

- відбір зразків для подальшого геохімічного їх аналізу:

- грунту з інтервалу глибин 0-5 і 5-10 cм

- та відкладів 3 грунтових профілів глибиною до 1,0 м у розрізах відслонень (розчистках).

Спостереження з відбором зазначених проб у натурних умовах виконані у 2018 і 2019 роках на 24 основних площадках, що приурочені до відмінних ландшафтно-геологічних умов (рис. 1). При цьому у межах кожної з площадок спостережень відібрано по кільканадцять зразків грунтових утворень. Це $\epsilon$ статистичною основою, щоб вважати результати аналізу по площадках адекватними. Географічна прив'язка площадок спостережень здійснювалася 3 застосуванням приладу GPS MAP 60 CSX 3 точністю прив'язки 5 м у системі координат UTM/WGS 84.

Природні умови площадок у межсах території полігона № 5 (це площадки № 20-24, рис. 2) описані нами в попередніх публікаціях $[17,23]$, в яких вони відповідають площадкам № 1-5 (див. рис. 2, 3 у [17]).

Отож, нижче зупинимося на характеристиці місцевості площадок спостережень поза контуром полігона № 5, але або безпосередньо біля нього, або ж у зоні імовірного його впливу. Так, якщо врахувати ландшафтногеоморфологічні умови території, передовсім гіпсометрію рельєфу сучасної земної поверхні (абсолютні відмітки, напрямок загального ухилу поверхні), що позначається на гідрологічних і гідрогеологічних iї умовах, то можна передбачити розташування площзадок № 1-3 в межах фонової стосовно полігона ділянки. Вони розміщені на прилеглій до річки Віта низовинній, порізаній меліоративними каналами, порослій лучною рослинністю рівнині, що розляглася східніше від вододільного пасма (рис. 3). 
Площадки спостережень № 4-14 локалізовані вже у межах вододільної поверхні безпосередньо уздовж південного, східного і північно-східного контуру карти «А» полігона № 5, переважно у 20-100 м від нього (рис. 2-6). Тобто вони вочевидь приурочені до буферної щодо полігона зони. При цьому площадки спостережень № 7 і 12 опробувалися і у 2018, і у 2019 році (зокрема у статті [12] вони відповідають площадкам № 5 і 7).

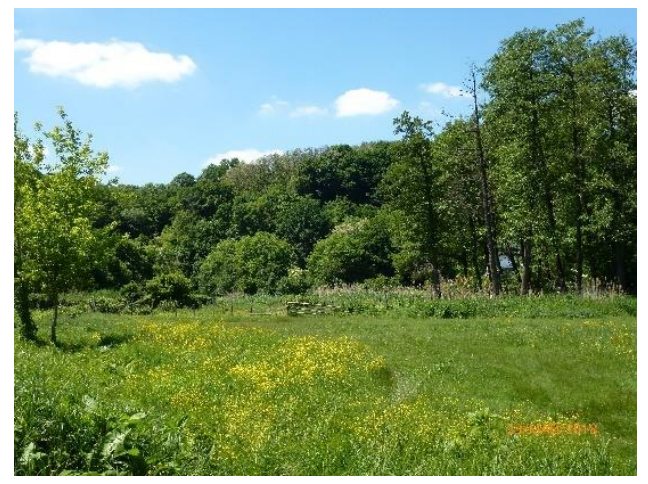

Рис. 3 - Фотографічне зображення порослої лучною рослинністю рівнини неподалік від підніжжя вододільного пасма (район площадки спостережень № 2)

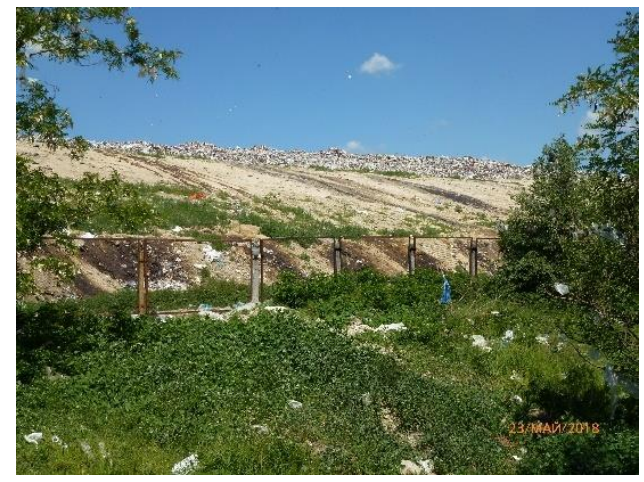

Рис. 4 - Фотографічне зображення району площадки спостережень № 10, на якому темно-коричневим кольором відмічаються місця височування фільтрату з тіла черги «А» полігона № 5

На площадках спостережень № 6, 13 і 14 зразки також отримано з грунтових профілів глибиною до 1,0 м 3 розрізів розчисток на місці наявних тут відслонень природного або техногенного походження.

Площуадки спостережень № 15 i 16 закладено на схилі від плато до долини невеликої річки з непостійним водотоком, а площадку № 17 - власне у вологій задернованій долині, безпосередньо біля підніжжя схилу (рис. 2).

Площзадк спостережень № 18 i 19 розташовані вже у північно-західній зоні впливу полігона, фактично вже в межах фонової ділянки (рис. 1, 7).

\section{Методи й теорія}

Для визначення особливостей латерального розподілу ВМ у грунтах території досліджень проби відібрано 3 поверхневих грунтових горизонтів (0-5 та 5-10 см) методом конверта відповідно до вимог ГОСТ 17.4.4.02-84 [28]. Для вивчення проникнення забруднення на глибину в натурних умовах досліджено грунтові профілі глибиною до 1,0 м. Опробування відповідних розчисток проводилось по горизонтах з інтервалом відбору 0,1 м.

Для визначення концентрацій хімічних елементів у зразках грунтів використано атомно-емісійний спектральний аналіз. Застосовувався також високочутливий метод ICP-MS (мас-спектрометрія з індукційно зв'язаною плазмою) для визначення форм знаходження ВМ у грунтах. Фізико-хімічні властивості грунтових відкладів визначалися за методикою Є.В. Арінушкіної [29]. Мінералогічний склад фракцій визначався за допомогою рентгенофазового аналізу на дифрактометрі Дрон-2 (Cuk $k_{\alpha}$-випромінювання). 
У разі потрапляння хімічних речовин у грунти у надлишкових кількостях найбільшу небезпеку являє собою збільшення вмісту саме рухомих форм. Останні можуть переходити у суміжні 3 грунтами середовища: поверхневі і підземні води, рослинні угруповання. Тому такий грунт являє собою реальну загрозу природному функціонуванню біогеоценозу.

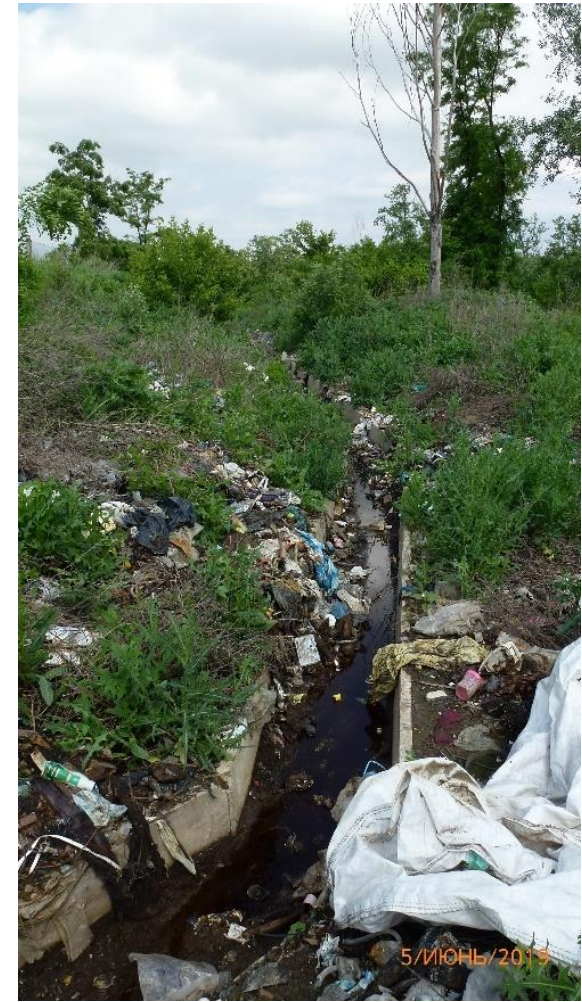

Рис. 5 - Фотографічне зображення бетонного захисного жолобу, що поблизу площадки спостережень № 12 значною мірою засмічений різноманітними побутовими відходами, а станом на 05.06.2019 р. був заповнений водою чорно-коричневого кольору

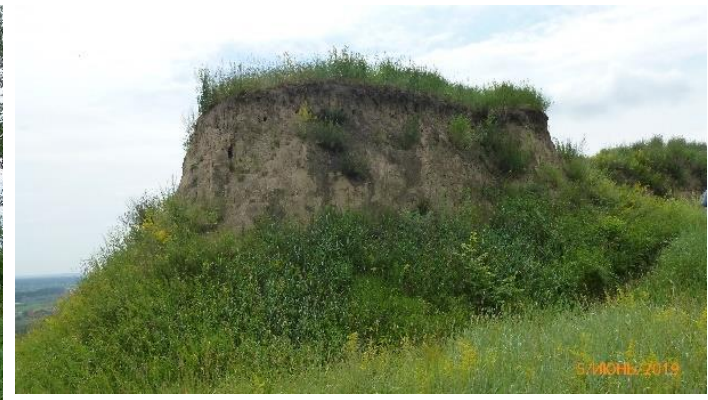

Рис. 6 - Фотографічне зображення відслонення на краю вододільного плато (район площадки спостережень № 14)

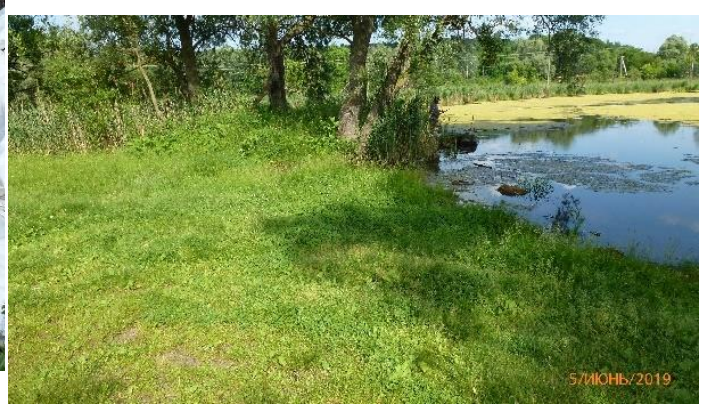

Рис. 7 - Фотографічне зображення площадки спостережень № 19, що на північному березі штучного ставка поблизу автодороги с. Креничі - с. Ходосівка

За високими значеннями рухомості мікроелементів констатують хімічне забруднення грунтів. Існують різні способи класифікації грунтів за їх властивістю інактивувати ВМ. Як критерій для кількісної еколого-геохімічної оцінки стійкості системи «грунт - розчин» та їі впливу на утворення мобільних форм ВМ використовувався, відповідно до розробленої групою авторів методики [30], коефіцієнт буферності $\left(К_{\sigma}\right)$ грунтів гумусового горизонту. Цей показник пропорційний сорбційній ємності грунтово-поглинаючого комплексу (CE) і обернено пропорційний зміні $\Delta \mathrm{pH}$ у системі «грунт розчин»:

$$
\mathrm{K}_{\tilde{\sigma}}=\mathrm{C} \mathrm{C} / \Delta \mathrm{pH} \text {. }
$$


Вивчення форм знаходження ВМ у грунтах проведено методом послідовного розчинення, що розроблений В.О. Кузнєцовим [31] і доповнений та модернізований А.І. Самчуком [30]. Метод базується на одночасному виділенні 3 грунту декількох елементів за допомогою “селективних" екстрагентів. Виділено такі форми знаходження ВМ у грунтах:

1) Водорозчинна форма. Форма знаходження, що включає в себе ВМ, які переходять у водну витяжку.

2) Обмінна. Обмінними називаються іони, що утримуються грунтом за рахунок електростатичних сил і які можуть бути заміщені еквівалентною кількістю іонів із нейтральних розчинів нейтральних солей. Вона представлена неміцно адсорбованими формами ВМ, зв'язаними 3 гідроксидами заліза, марганцю, кремнію, органічною речовиною, глинистими мінералами.

3) Зв'язана з карбонатами форма об'єднує сорбовані карбонатами ВМ та ізоморфні домішки.

4) Сорбована на аморфних гідроксидах заліза, марганцяю. Представлена іонами ВМ, що поглинуті гідроксидами заліза, марганцю. Тобто сукупністю форм металів, що утворюють поверхневі комплекси, які переходять в розчин при руйнуванні гідроксидів заліза і марганцю.

5) Зв'язана 3 органічною речовиною. Представлена міцними металоорганічними комплексами (комплексні сполуки іонів ВМ з гуміновими кислотами).

6) Важкорозчинна форма об'єднує метали, що входять у кристалічну решітку породотвірних і акцесорних мінералів.

Отримані за результатами лабораторних досліджень дані стосовно геохімічних особливостей зразків грунту району робіт аналітично порівнювалися з аналогічними параметрами фонових грунтів, які характерні для території, що розглядається, загалом (лісостепу правобережного високого). При цьому за основу взято дані, наведені у праці [26].

\section{Виклад основного матеріалу досліджень й обгрунтування отриманих наукових результатів}

3 метою оцінки екологічного стану сучасних грунтів під час спільних польових досліджень на території полігона № 5 та у районі його впливу нами було досліджено три їхні розрізи у трьох різних розчистках. Отож нижче насамперед зупинимося на характеристиці типів грунтів, яку вдалося визначити. Детальний аналіз морфологічних (забарвлення, структура, гранулометричний склад, вологість, складення, новоутворення, включення, перехід між горизонтами, межа) особливостей сучасних грунтів у розрізах дозволили встановити типи цих відкладів.

Грунти у першу чергу відзначаються темно-сірим забарвленням їх профілю, грудкуватою структурою, легким суглинковим гранулометричним складом, 3 включеннями червориїн і кротовин, новоутвореннями карбонатів у вигляді міцелію, а також поступовими переходами між генетичними горизонтами (H, Hk, PHk, Phk, Pk). За цими ознаками грунти є близькими до чорноземів типових, які сформувалися на лесових відкладах бузького часу. I саме ці лесові відклади використовуються для засипання i подальшого захоронення побутових відходів на території полігона № 5. 
Для більш детального уточнення генезису грунтів і оцінки ступеня їх забруднення були також відібрані зразки на мікроморфологічний аналіз. Подальші результати мікроморфологічного аналізу сучасних чорноземних грунтів дозволять не тільки оцінити ступінь забрудненості (виявлення часточок під мікроскопом), але й уточнити їх генезис (для правильного застосування заходів з вилучення полютантів і поліпшення екологічного стану як власне відкладів, так і навколишнього середовища загалом).

Дослідження гранулометричного складу грунтів зони аерації району полігона № 5 показали, що вміст піщаної фракції в них змінюється в межах 1-6\%, алевритової - 3-10\%, а вміст глинистої фракції становить 84-90\%. Отже, глиниста фракція є переважаючою для грунтових відкладів досліджуваної території та є основним сорбентом для полютантів. Основними глинистими мінералами цієї фракції є монтморилоніт, гідрослюда (типу іліту), каолініт.

Встановлено такий хімічний склад досліджуваних зразків грунтів: $\mathrm{SiO}_{2}$ від 49 до 82\%, $\mathrm{Al}_{2} \mathrm{O}_{3}-4-8 \%$. У пробах грунтів, відібраних під час досліджень безпосередньо на території полігона, максимальне перевищення фонового, згідно з [26], вмісту мікроелементів зафіксовано для таких ВМ: міді, свинцю, цинку, нікелю та олова. Зокрема, вміст цинку у грунтах власне полігона № 5 досягає 500 г/т, при фоновому вмісті для Дніпровської лісостепової геохімічної провінції 48 г/т. Максимальна концентрація міді досягає 600 г/т при фоновому вмісті 20 г/т, тобто реєструється тридцятикратне перевищення фонових показників (рис. 8).

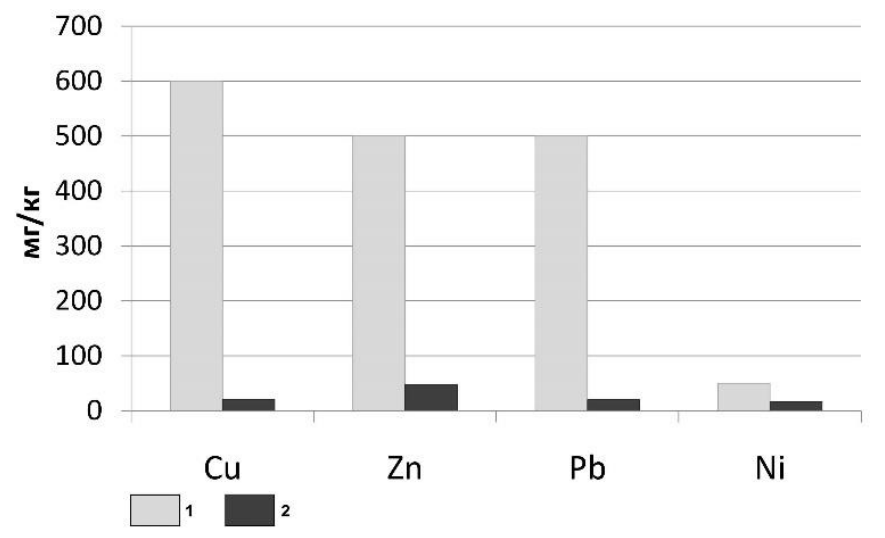

Рис. 8 - Порівняння максимального перевищення вмісту важких металів у техногенно забруднених грунтах району карти «А» полігона № 5 фонового у грунтах території досліджень. 1 - максимальний вміст ВМ у досліджених грунтах карти «А» полігона, 2 - вміст ВМ у фонових [26] грунтах

Найбільший вміст свинцю у грунтах у межах полігона має значення 500 г/т, що у 25 разів більше за фоновий показник $(20$ г/т). Тут же зафіксовано високу концентрацію нікелю - 50 г/т при його фоновому вмісті 16 г/т. Відмічено також високий вміст олова, що у понад 20 разів перевищує фонове його значення.

У буферній зоні полігона № 5, тобто в районі поза його межами, але такому, що зазнає його впливу, також відмічаються концентрації мікроелементів у 
грунтах, які у 2-3 рази перевищують фонові значення. Це характерно для міді, свинцю, цинку, нікелю, хрому, олова.

На підставі проведених досліджень одержано результати фізико-хімічних властивостей грунтів гумусового горизонту як на території полігона, так і за його контуром. Зокрема, за межами полігона визначено такі показники грунтів: $\mathrm{C}_{\text {орг. }}-6,2 \%, \mathrm{pH}-6,5$; вміст обмінних катіонів, мг-екв./100 г: $\mathrm{H}^{+}-8,2$, $\mathrm{Ca}^{2+}-39,0, \mathrm{Mg}^{2+}-12,8, \mathrm{~K}^{+}-0,7, \mathrm{Na}^{+}-0,65$; сума обмінних катіонів - 61,35. Натомість, фізико-хімічні властивості грунтів, відібраних у межах полігона, значно відрізняються від наведених нижчими значеннями, що вказує на їхні зміни: $\mathrm{C}_{\text {огр. }}-3,6 \%, \mathrm{pH}-6,3$; вміст обмінних катіонів, мг-екв./100 г: $\mathrm{H}^{+}-3,2$, $\mathrm{Ca}^{2+}-12,0, \mathrm{Mg}^{2+}-4,9, \mathrm{~K}^{+}-0,3, \mathrm{Na}^{+}-0,4$; сума обмінних катіонів - 20,8. Не викликає сумнівів, що зазначені зміни відбулися під дією різноманітних токсикантів, пов'язаних з діяльністю об'єкта захоронення ТПВ.

Отримані дані дозволили розрахувати за формулою (1) коефіцієнт буферності грунтів гумусового горизонту. Так, для грунтів поза контуром полігона № 5, що імовірно зазнають впливу північно-східної, північної та північно-західної його частин, одержано значення $\mathrm{K}_{\sigma}=55$. Для техногенно забруднених грунтових утворень карти «А» полігона Кб зменшується майже удвічі.

Дослідженнями виконано еколого-геохімічне оцінювання впливу полігона захоронення ТВП № 5 на стан грунтів у його межах. Для цього встановлено форми знаходження ВМ у грунтовому покриві полігона, які найбільше перевищують відповідні фонові значення: свинцю, цинку, міді. У результаті проведених аналітичних робіт визначено, що вміст рухомих форм (водорозчинної та іонообмінної) у грунтових утвореннях, які найбільше впливають на екологічну оцінку території, зростає: для міді та цинку - у 2 рази, для свинцю - у 8 разів. Саме вміст рухомих форм здійснює вплив на міграцію ВМ у трофічному ланцюгу «грунт - розчин - біота».

Отже, порівняння геохімічних особливостей зразків техногенно забруднених грунтів полігона і прилеглих до нього районів з пробами фонових грунтів дозволяє констатувати таке. Від часу введення в дію у 1986 році полігона № 5 захоронення ТВП через порушення в його експлуатації, що зумовлені недотриманням технології пересипки складованих відходів ізоляційним шаром землі, нерегулярною роботою установки 3 переробки фільтрату, перевищенням потужностей тощо, грунти в його межах і навіть у буферній до нього зоні зазнали забруднення різноманітними токсичними речовинами, зокрема ВМ.

Справедливості заради потрібно зазначити, що в останні роки зусиллями підприємства Приватне акціонерне товариство «Київспецтранс», що надає послуги з захоронення ТПВ на полігоні, інтенсивно провадяться роботи щодо підвищення його безпеки та підготовки до рекультивації. Вони полягають у ліквідації аварійних схилів карти «А» полігона, розширенні потужностей переробки фільтрату, укріпленні та оновленні захисних дамб (особливо дамби західніше карти «Б»). Як наслідок виніс забруднювачів 3 території полігона за його межі й негативна їх дія на компоненти довкілля поступово зменшуються. Це зафіксовано нашими дослідженнями [18, 19, 22]. 


\section{Висновки й перспективи подальших розвідок у цьому напрямі}

У результаті проведених аналітичних робіт та підсумків попередніх етапів досліджень встановлено істотне забруднення грунтового шару важкими металами, передусім у межах полігона № 5. Виявлено також негативний його вплив на вміст цих полютантів у грунтах буферної, прилеглої до нього зони. Це стало наслідком майже 34-річного функціонування об'єкта захоронення ТВП, протягом якого мали місце порушення в його експлуатації.

Так, для грунтових відкладів полігона визначено максимальне перевищення фонового вмісту міді, свинцю, цинку, нікелю та олова від декількох до десятків разів, у той же час поза його контуром - у 2-3 рази. Зафіксовані негативні зміни фізико-хімічних властивостей грунтів гумусового горизонту при порівнянні відповідних показників за зразками, відібраними у прилеглих до полігона районах і безпосередньо на його території. Коефіцієнт буферності грунтів цього горизонту майже удвічі менший на техногенно забруднених землях об'єкта захоронення ТВП, ніж на відносно фонових ділянках.

Вміст рухомих форм ВМ у грунтових утвореннях полігона № 5 порівняно 3 фоновими значення зростає у 2 рази для міді та цинку, а для свинцю - у 8 разів.

Для подальшого з'ясування механізму міграції забруднювачів у компонентах довкілля території досліджень (грунти - природні води рослинність) необхідно здійснити еколого-геохімічне їх опробування по регулярній мережі наземних площадок. Потреба також є у спрямуванні зусиль фахівців у плані оцінки сезонного впливу полігона на стан навколишнього середовища загалом.

\section{Подяка}

Автори висловлюють вдячність керівництву ПрАТ «Київспецтранс» за дозвіл на в’їзд на територію полігона № 5 протягом 2019 р. і фотографування відповідної місцевості протягом 2019 р., а також за дозвіл щодо відбору проб грунту, які були використані для лабораторно-камерального аналізу на вміст важких металів і для оцінки можливого впливу об'єкта захоронення ТПВ на довкілля.

\section{СПИСОК ЛІТЕРАТУРИ}

1. Стан сфери поводження з побутовими відходами в Україні за 2019 рік. - К.: Мінрегіон України, 2020. - Режим доступу: https://www.minregion.gov.ua/napryamkidiyalnosti/zhkh/terretory/stan-sfery-povodzhennya-z-pobutovymy-vi/.

2. Bauer M.J. Chemodynamics, transport behaviour and treatment of phthalic acid esters in municipal landfill leachates / M.J. Bauer, R. Herrmann, A. Martin, H. Zellmann // Wat. Sci. Tech. - 1998. - Vol. 38, No 2. - P. 185-192. - https://search.proquest.com/ openview/ff40061 ef856211c1411206e 7c834ffa/1 ?pq-origsite $=$ gscholar\&cbl=2044520.

3. Aluko O.O. Characterization of leachates from a municipal solid waste landfill site in Ibadan, Nigeria / O.O. Aluko, M.K.C. Sridhar, P.A. Oluwande // J. Environ. Health Res. 2003. - Vol. 2, iss. 1. - P. 32-37. - https://www.researchgate.net/profile/Olufemi_Aluko2/ publication/274243919_Characterization_of_leachates_from_a_municipal_solid_waste_lan dfill_site_in_Ibadan_Nigeria/links/55195a1c0cf2d241f35638bf/Characterization-ofleachates-from-a-municipal-solid-waste-landfill-site-in-Ibadan-Nigeria.pdf. 
4. Abu-Zeid N. Geochemical characterisation and geophysical mapping of Landfill leachates: the Marozzo canal case study (NE Italy)/ N. Abu-Zeid, G. Bianchini, G. Santarato, C. Vaccaro // Environ. Geol. - 2004. - Vol. 45. - P. 439-447. doi: https://doi.org/10.1007/s00254-003-0895-x.

5. Słomczyńska B. Physico-chemical and toxicological characteristics of leachates from MSW landfills / B. Słomczyńska, T. Słomczyński // Pol. J. Environ. Stud. - 2004. - Vol. 13, No 6. - P. 627-637. - https://pdfs.semanticscholar.org/f6cc/20d54e7074ad55439d5b 468305c227fde101.pdf.

6. Mor S. Leachate characterization and assessment of groundwater pollution near municipal solid waste landfill site / S. Mor, K. Ravindra, R.P. Dahiya, A. Chandra // Environ. Monit. Assess. - 2006. - Vol. 118. P. 435-456.

https://doi.org/10.1007/s10661-006-1505-7.

7. Øygard J.K. Uranium in municipal solid waste landfill leachate / J.K. Øygard , E. Gjengedal // Int. J. Environ. Res. - 2009. - Vol. 3, iss. 1. - P. 61-68. http://www.bioline.org.br/request?er09007.

8. Шевченко М. Екологічна оцінка впливу полігонів твердих побутових відходів Кіровоградської області на стан навколишнього середовища / М. Шевченко, О.В. Медведєва // Наук. зап. - Кіровоград: КДПУ ім. В. Винниченка, 2010. - Вип. 10, ч. II. - C. 313-315. - Режим доступу: http://dspace.kntu.kr.ua/jspui/bitstream/ 123456789/5425/1/68.pdf.

9. Adeolu O.A. Assessment of groundwater contamination by leachate near a municipal solid waste landfill / O.A. Adeolu, V.O. Ada, A.A. Gbenga, A.O. Adebayo // Afr. J. Environ. Sci. Tech. - 2011. - Vol. 5, iss. 11. - P. 933-940. - DOI: 10.5897/AJEST11.27.

10. Bhalla B. Effect of age and seasonal variations on leachate characteristics of municipal solid waste landfill / B. Bhalla, M.S. Saini, M.K. Jha // Int. J. Res. Engineering Tech. - 2013. Vol. 02, iss. 08. - P. 223-232. - http://citeseerx.ist.psu.edu/viewdoc/download? doi=10.1.1.681.5957\&rep=rep1\&type=pdf.

11. Azimov O.T. Reconnaissance integrated geoecological study of the disposal region for municipal solid waste with the aim of environmental assessment / O.T. Azimov, V.G. Bakhmutov, Yu.Yu. Voytyuk, Ye.M. Dorofey, S.P. Karmazynenko, I.V. Kuraeva // 12th Int. Conf. on Monitoring of Geological Processes and Ecological Condition of the Environment (13-16 November 2018, Kyiv, Ukraine): Extended Abstracts. - 2018. - 5 p. DOI: $10.3997 / 2214-4609.201803142$.

12. Азімов О.Т. Моніторинг територій полігонів твердих побутових відходів 3 використанням дистанційних технологій / О.Т. Азімов, О.В. Томченко, С.П. Кармазиненко, І.В. Кураєва, Ю.Ю. Войтюк // Формування програм щодо поводження з відходами для об'єднаних територіальних громад: проблемні питання та кращі практики: Зб. матеріалів Нац. форуму «Поводження 3 відходами в Україні: законодавство, економіка, технології» (Київ, 22-23 листоп. 2018 р.). - К.: Центр еколог. освіти та інформації, 2018. - С. 84-87.

13. Азімов О.Т. Еколого-геохімічна оцінка об'єктів довкілля територій поховання твердих побутових відходів / О.Т. Азімов, І.В. Кураєва, Ю.Ю. Войтюк, А.І. Самчук, С.П. Кармазиненко, В.Г. Бахмутов // Пошукова та екологічна геохімія. - 2018. № 1 (19). - С. 22-26.

14. Азимов А.Т. Анализ результатов комплексных геохимических исследований образцов компонентов ландшафта из зоны влияния мест захоронения твердых бытовых отходов / А.Т. Азимов, С.П. Кармазиненко, И.В. Кураева, Ю.Ю. Войтюк // Сб. науч. тр. по материалам Междунар. науч. экол. конф. «Отходы, причины их образования и перспективы использования» (г. Краснодар, 26-27 марта 2019 г.). Сост. Л.С. Новопольцева, под ред. И.С. Белюченко. - Краснодар: КубГАУ, 2019. - С. 198 200. - Режим доступу: http://www.ecokavkaz.ru/media/docs/conf/conf2019.pdf.

15. Azimov O.T. Estimation of the heavy metal pollution for the soils and different environmental objects within the solid domestic waste landfills / O.T. Azimov, I.V. Kuraeva, O.M. Trofymchuk, S.P. Karmazynenko, Ye.M. Dorofey, Yu.Yu. Voytyuk // 18th EAGE Int. 
Conf. on Geoinformatics - Theoretical and Applied Aspects (13-16 May 2019, Kyiv, Ukraine): Conference Papers. - 2019. - 7 p. - DOI: 10.3997/2214-4609.201902129.

16. Азімов О.Т. Раціональний комплекс геохімічних методів при дослідженні довкілля районів поховання твердих побутових відходів / О.Т. Азімов, І.В. Кураєва, С.П. Кармазиненко, К.С. Злобіна // Актуальні проблеми та перспективи розвитку геології: наука й виробництво: Матеріали VI Міжнар. геол. форуму (17-22 черв. 2019 р., м. Одеса, Україна). - К.: УкрДГРІ, 2019. - С. 13-16. - Режим доступу: http://ukrdgri.gov.ua/wp-content/uploads/2019/06/material_geoforum_2019_1.pdf.

17. Азімов О.Т. Оцінка вмісту важких металів у грунтах та інших компонентах ландшафту в районах захоронення твердих побутових відходів / О.Т. Азімов, О.М. Трофимчук, І.В. Кураєва, С.П. Кармазиненко // Екологічна безпека та природокористування. - $2019 . \quad-$ Вип. 2(30). - С. 5-17. DOI: https://doi.org/10.32347/2411-4049.2019.2.5-17.

18. Трофимчук О.М. Особливості моніторингу гідросферних процесів у межах техноекосистем територій захоронення твердих побутових відходів з застосуванням дистанційних технологій / О.М. Трофимчук, О.Т. Азімов, І.В. Кураєва, К.С. Злобіна, С.П. Кармазиненко // Колективна монограф. за матеріалами XVIII Міжнар. наук.практ. конф. «Сучасні інформаційні технології управління екологічною безпекою, природокористуванням, заходами в надзвичайних ситуаціях: актуальні питання» (Київ, 01-02 жовт. 2019 р.). За заг. ред. С.О. Довгого. - К.: ТОВ «Вид-во «Юстон», 2019. - С. 72-76. - Режим доступу: https://itgip.org/wp-content/uploads/2019/10/1_ Книга_сайт.pdf.

19. Azimov O.T. Monitoring and assessment of impact of municipal solid waste landfills on the surface water quality in the adjacent ponds / O.T. Azimov, Ye.M. Dorofey, O.M. Trofymchuk, I.V. Kuraeva, K.S. Zlobina, S.P. Karmazynenko // 13th Int. Sci. Conf. on Monitoring of Geological Processes and Ecological Condition of the Environment (12-15 November 2019, Kyiv, Ukraine): Conference Papers. - 2019. - 6 p. - DOI: 10.3997/22144609.201903228.

20. Азімов О.Т. Оцінка розподілу важких металів у грунтах районів захоронення твердих побутових відходів / О.Т. Азімов, І.В. Кураєва, В.Г. Бахмутов, Ю.Ю. Войтюк, С.П. Кармазиненко // Вісн. Київ. нац. ун-ту ім. Тараса Шевченка. Геологія. - 2019. Вип. 4 (87). - С. 76-80. - Режим доступу: http://geolvisnyk.univ.kiev.ua/archive/ 2019/N4(87)/Azimov.pdf.

21. Kaliaskarova Z.K. Soil pollution with heavy metals on the land of the Karasai landfill of municipal solid waste in Almaty city / Z.K. Kaliaskarova, Zh.N. Aliyeva, A.S. Ikanova, E.S.M. Negim // News Acad. Sciences Republic Kazakhstan: Geol. Tech. Sci. - 2019. Vol. 6, No 438. - P. 256-267. - https://doi.org/10.32014/2019.2518-170X.177.

22. Азимов А.Т. Мониторинг качества поверхностных вод районов захоронения твердых бытовых отходов / А.Т. Азимов, Е.С. Злобина, С.П. Кармазиненко, И.В. Кураева // Сб. науч. тр. по материалам Междунар. науч. экол. конф. «Аграрные ландшафты, их устойчивость и особенности развития» (г. Краснодар, 24-26 марта 2020 г.) / Сост. Л.С. Новопольцева; под ред. И.С. Белюченко. - Краснодар: КубГАУ, 2020. - С. 340-343. - Режим доступу: http://ecokavkaz.ru/media/docs/conf/conf2020.pdf. 23. Азімов О.Т. Забруднення грунтів та інших об'єктів довкілля важкими металами в районах полігонів захоронення твердих побутових відходів / О.Т. Азімов, І.В. Кураєва, О.М. Трофимчук, С.П. Кармазиненко, К.С. Злобіна // Геоінформатика. - 2020. № 1 (73). - С. 82-98. - Режим доступу: http://www.geology.com.ua/.

24. Azimov O.T. Ecological and geochemical study of the state of soil deposits in the impact areas of municipal solid waste landfills / O.T. Azimov, O.M. Trofymchuk, I.V. Kuraeva, K.S. Zlobina, S.P. Karmazinenko, Ye.M. Dorofey // 19th EAGE Int. Conf. on Geoinformatics - Theoretical and Applied Aspects (11-14 May 2020, Kyiv, Ukraine): Conference Papers. - 2020. - 7 p. - Режим доступу: https://eage.in.ua/wpcontent/uploads/2020/05/17388.pdf. 
25. Кармазиненко С.П. Важкі метали у компонентах навколишнього середовища м. Маріуполь (еколого-геохімічні аспекти) / С.П. Кармазиненко, І.В. Кураєва, А.І. Самчук, Ю.Ю. Войтюк, В.Й. Манічев. - К.: Інтерсервіс, 2014. 168 с. - Режим доступу: https://igu.org.ua/sites/default/files/pdf-text/heavy-metals-m.pdf.

26. Люта Н.Г. Про використання геохімічних критеріїв (фонів та сумарного показника забруднення) для оцінки геохімічного стану ландшафтів / Н.Г. Люта // Зб. наук. пр. УкрДГРІ. - 2004. - № 2. - С. 162-169.

27. https://www.google.com/maps.

28. Охрана природы. Почвы. Методы отбора и подготовки проб для химического, бактериологического, гельминтологического анализа: ГОСТ 17.4.4.02-84. [Действующий от 1986-01-01]. - Москва: Стандартинформ, 2008. - 8 с.

29. Аринушкина Е.В. Руководство по химическому анализу почв / Е.В. Аринушкина / [2-е изд., перераб. и доп.]. - Москва: Изд-во МУ, 1970. - 488 с.

30. Самчук А.И. Физико-химические условия образования мобильных форм токсичных металлов в почвах / А.И. Самчук, Г.Н. Бондаренко, В.В. Долин, Ю.Я. Сущик, И.Ф. Шраменко, Б.Ф. Мицкевич, О.С. Егоров // Минерал. журн. - 1998. Т. 20, № 2. - C. 48-59.

31. Кузнецов В.А. Метод постадийных вытяжек при геохимических исследованиях / В.А. Кузнецов, Г.А. Шимко. - Минск: Наука и техника, 1990. - 88 с.

Стаття надійшла до редакиії 17.04.2020 і прийнята до друку після рецензування 24.07.2020

\section{REFERENCES}

1. State of the municipal waste treatment sphere in Ukraine for 2019 (2020) Kyiv: Ministry for Communities and Territories Development of Ukraine. https://www.minregion.gov.ua/napryamki-diyalnosti/zhkh/terretory/stan-sfery-povodzhennyaz-pobutovymy-vi/. (in Ukrainian).

2. Bauer, M.J., Herrmann, R., Martin, A., \& Zellmann, H. (1998) Chemodynamics, transport behaviour and treatment of phthalic acid esters in municipal landfill leachates. Wat. Sci. Tech., $\quad 38(2), \quad$ 185-192. https://search.proquest.com/openview/ ff40061 ef856211c1411206e 7c834ffa/1 ?pq-origsite=gscholar\&cbl=2044520.

3. Aluko, O.O., Sridhar, M.K.C., \& Oluwande, P.A. (2003) Characterization of leachates from a municipal solid waste landfill site in Ibadan, Nigeria. J. Environ. Health Res., 2 (1), 32-37. https://www.researchgate.net/profile/Olufemi_Aluko2/publication/274243919_ Characterization_of_leachates_from_a_municipal_solid_waste_landfill_site_in_Ibadan_Ni geria/links/55195a1c0cf2d241f35638bf/Characterization-of-leachates-from-a-municipalsolid-waste-landfill-site-in-Ibadan-Nigeria.pdf.

4. Abu-Zeid, N., Bianchini, G., Santarato, G., \& Vaccaro, C. (2004) Geochemical characterisation and geophysical mapping of Landfill leachates: the Marozzo canal case study (NE Italy). Environ. Geol., 45, 439-447, doi: https://doi.org/10.1007/s00254-0030895-x.

5. Słomczyńska, B., \& Słomczyński, T. (2004) Physico-chemical and toxicological characteristics of leachates from MSW landfills. Pol. J. Environ. Stud., 13 (6), 627-637. https://pdfs.semanticscholar.org/f6cc/20d54e7074ad55439d5b468305c227fde101.pdf.

6. Mor, S., Ravindra, K., Dahiya, R.P., \& Chandra, A. (2006) Leachate characterization and assessment of groundwater pollution near municipal solid waste landfill site. Environ. Monit. Assess., 118, 435-456. https://doi.org/10.1007/s10661-006-1505-7.

7. Øygard, J.K., \& Gjengedal, E. (2009) Uranium in municipal solid waste landfill leachate. Int. J. Environ. Res., 3 (1), 61-68. https://ijer.ut.ac.ir/article_33.html.

8. Shevchenko, M., \& Medvedieva, O.V. (2010) Ecological evaluation of the impact of solid waste landfills on the state of environment. Naukovi zapysky - Academic Notes 
(Ukraine). Kirovohrad: Kirovohrad Volodymyr Vynnychenko State Pedagogical Univ., iss. 10, part II, 313-315. http://dspace.kntu.kr.ua/jspui/bitstream/123456789/5425/1/68.pdf. (in Ukrainian with English summary).

9. Adeolu, O.A., Ada, V.O., Gbenga, A.A., \& Adebayo, A.O. (2011) Assessment of groundwater contamination by leachate near a municipal solid waste landfill. Afr. J. Environ. Sci. Tech., 5 (11), 933-940, doi: 10.5897/AJEST11.27.

10. Bhalla, B., Saini, M.S., \& Jha, M.K. (2013) Effect of age and seasonal variations on leachate characteristics of municipal solid waste landfill. Int. J. Res. Engineering Tech., 02 (08), 223-232. http://citeseerx.ist.psu.edu/viewdoc/download?doi=10.1.1.681.5957\&rep $=$ rep $1 \&$ type $=$ pdf.

11. Azimov, O.T., $\quad$ Bakhmutov, V.G., $\quad$ Voytyuk, Yu.Yu., $\quad$ Dorofey, Ye.M., Karmazynenko, S.P., \& Kuraeva, I.V. (2018) Reconnaissance integrated geoecological study of the disposal region for municipal solid waste with the aim of environmental assessment. 12th Int. Sci. Conf. on Monitoring of Geological Processes and Ecological Condition of the Environment (13-16 November 2018, Kyiv, Ukraine), Extended Abstr., 5 p., doi: 10.3997/2214-4609.201803142.

12. Azimov, O.T., Tomchenko, O.V., Karmazynenko, S.P., Kuraeva, I.V., \& Voytyuk, Yu.Yu. (2018) Monitoring the municipal solid waste landfill areas using the remote sensing technologies. Program development on the waste management for the united territorial communities: key problematic issues and the best practices: Proc. National Forum "Waste management in Ukraine: legislation, economics, technologies" (Kyiv, 22-23 November 2018). Kyiv: Centre for the ecological education and information, 84-87. (in Ukrainian).

13. Azimov, O.T., Kuraeva, I.V., Voytyuk, Yu.Yu., Samchyk, A.I., Karmazynenko, S.P., \& Bakhmutov, V.G. (2018) Ecological-geochemical assessment of the territories for the municipal solid waste disposal. Poshukova ta ekolohichna geokhimiia - Explor. Environ. Geochem. (Ukraine), 1 (19), 22-26. (in Ukrainian with English summary).

14. Azimov, O.T., Karmazynenko, S.P., Kuraeva, I.V., \& Voytyuk, Yu.Yu. (2019) Analysis of the results of the complex geochemical investigations of samples for the landscape components within the affected zone of municipal solid waste disposal areas. Proc. Int. Sci. Ecological Conf. "Waste, the reasons of their formation and prospects of utilization" (Krasnodar city, 26-27 March 2019); Compiler Novopoltseva, L.S.; Ed. Beliuchenko, I.S. Krasnodar: Kuban State Agrarian Univ., 198-200. http://www.ecokavkaz.ru/media/docs/conf/conf2019.pdf. (in Russian).

15. Azimov, O.T., Kuraeva, I.V., Trofymchuk, O.M., Karmazynenko, S.P., Dorofey, Ye.M., \& Voytyuk, Yu.Yu. (2019) Estimation of the heavy metal pollution for the soils and different environmental objects within the solid domestic waste landfills. 18th EAGE Int. Conf. on Geoinformatics - Theoretical and Applied Aspects (13-16 May 2019, Kyiv, Ukraine), Conf. Pap., 7 p., doi: 10.3997/2214-4609.201902129.

16. Azimov, O.T., Kuraeva, I.V., Karmazynenko, S.P., \& Zlobina, K.S. (2019) Rational complex for the geochemical methods in the environment study of the municipal solid waste disposal areas. Proc. 6th Int. Geol. Forum "Actual problems and prospects of the development of geology: science and production" (17-22 June 2019, Odesa, Ukraine). Kyiv: UkrSGRI, 13-16. http://ukrdgri.gov.ua/wp-content/uploads/2019/06/material_geoforum 2019 1.pdf. (in Ukrainian with English summary).

17. Azimov, O.T., Trofymchuk, O.M., Kuraeva, I.V., \& Karmazinenko, S.P. (2019) Estimations of heavy metals in soils and different landscape components within the municipal solid waste disposal areas. Ekolohichna bezpeka ta pryrodokorystuvannia - Environ. Safety Nat. Resources (Ukraine), 2 (30), 5-17, doi: https://doi.org/10.32347/2411-4049.2019.2.517. (in Ukrainian with English abstract).

18. Trofymchuk, O.M., Azimov, O.T., Kuraeva, I.V., Zlobina, K.S., \& Karmazynenko, S.P. (2019) Features of the monitoring hydrosphere processes within the techno-ecosystems of the solid municipal waste disposal areas using remote sensing technologies. In: Dovhyi, S.O. (Ed.) Multi-authored monograph based on Proc. 18th Int. Sci. \& Practical Conf. "Modern 
Information Technologies of the Ecological Management, Natural Resource Use and Emergency Measures: Topical Issues" (Kyiv, 01-02 October 2019). Kyiv: LLC Yuston Press, 72-76. https://itgip.org/wp-content/uploads/2019/10/1_\%D0\%9A\%D0\%BD\%D0\% B8\%D0\%B3\%D0\%B0_\%D1\%81\%D0\%B0\%D0\%B9\%D1\%82.pdf. (in Ukrainian).

19. Azimov, O.T., Dorofey, Ye.M., Trofymchuk, O.M., Kuraeva, I.V., Zlobina, K.S., \& Karmazynenko, S.P. (2019) Monitoring and assessment of impact of municipal solid waste landfills on the surface water quality in the adjacent ponds. 13th Int. Sci. Conf. on Monitoring of Geological Processes and Ecological Condition of the Environment (12-15 November 2019, Kyiv, Ukraine), Conf. Pap., 6 p., doi: 10.3997/2214-4609.201903228.

20. Azimov, O., Kuraeva, I., Bakhmutov, V., Voytyuk, Yu., \& Karmazynenko, S. (2019) Assessment of the heavy metal distribution in soils within the areas for the municipal solid waste disposal. Visnyk Kyivskoho natsionalnoho universytetu imeni Tarasa Shevchenka. Heolohiia - Visnyk (Bull.) Taras Shevchenko National Univ. of Kyiv: Geol. (Ukraine), 4 (87), 76-80. http://geolvisnyk.univ.kiev.ua/archive/2019/N4(87)/Azimov.pdf. (in Ukrainian with English abstract).

21. Kaliaskarova, Z.K., Aliyeva, Zh.N., Ikanova, A.S., \& Negim, E.S.M. (2019) Soil pollution with heavy metals on the land of the Karasai landfill of municipal solid waste in Almaty city. KR YGA Habarlary. Heolohiya men tehnikalyk hylymdar seriyasy-News Acad. Sci. Republic Kazakhstan: Geol. Tech. Sci., 6 (438), 256-267. https://doi.org/10.32014/2019.2518-170X.177.

22. Azimov, O.T., Zlobina, K.S., Karmazinenko, S.P., \& Kuraeva, I.V. (2020) Monitoring surface water quality in the regions of municipal solid waste disposal. Proc. Int. Sci. Ecological Conf. "Agricultural landscapes, their stability, and the development features" (Krasnodar city, 24-26 March 2020); Compiler Novopoltseva, L.S.; Ed. Beliuchenko, I.S. Krasnodar: Kuban State Agrarian Univ., 340-343. http://ecokavkaz.ru/media/docs/conf/conf2020.pdf. (in Russian).

23. Azimov, O.T., Kuraeva, I.V., Trofymchuk, O.M., Karmazinenko, S.P., \& Zlobina, K.S. (2020) The heavy metal pollution for the soils and different environmental objects within the areas of municipal solid waste landfills. Geoinformatyka - Geoinformatics (Ukraine), 1 (73), 82-98. http://www.geology.com.ua/. (in Ukrainian with English abstract).

24. Azimov, O.T., Trofymchuk, O.M., Kuraeva, I.V., Zlobina, K.S., Karmazinenko, S.P., \& Dorofey, Ye.M. (2020) Ecological and geochemical study of the state of soil deposits in the impact areas of municipal solid waste landfills. 19th EAGE Int. Conf. on Geoinformatics Theoretical and Applied Aspects (11-14 May 2020, Kyiv, Ukraine), Conf. Pap., 7 p. https://eage.in.ua/wp-content/uploads/2020/05/17388.pdf.

25. Karmazynenko, S.P., Kuraeva, I.V., Samchuk, A.I., Voitiuk, Iu.Iu., \& Manichev, V.I. (2014) Heavy metals in the components of the environment Mariupol City: Ecological and geochemical aspects. Kyiv: Interservis. https://igu.org.ua/sites/default/files/pdf-text/heavymetals-m.pdf). (in Ukrainian with English abstract).

26. Lyuta, N.G. (2004) On application of geochemical criteria (backgrounds and total pollution index) for the assessment of landscapes geochemical conditions. Zbirnyk naukovyh prats UkrDGRI - Sci. Proc. UkrSGRI (Ukraine), 2, 162-169. (in Ukrainian with English summary).

27. https://www.google.com/maps.

28. Environmental protection. Soils. Methods of sampling and preparing of samples for the chemical, bacteriological, and helminthological analyses: GOST 17.4.4.02-84 (2008). [Acting after 1986-01-01]. Moscow: Standardinform. (in Russian).

29. Arinushkina, E.V. (1970) Manual on soil chemical analysis. 2nd Eds, revised and enlarged. Moscow: Moscow Univ. Press. (in Russian).

30. Samchuk, A.I., Bondarenko, G.N., Dolin, V.V., Sushchik, Yu.Ya., Shramenko, I.F., Mitskevich, B.F., \& Egorov, O.S. (1998) Physical and chemical conditions promoting formation of mobile forms of toxic metals in soils. Mineralogicheskiy zhurnal-Mineral. J. (Ukraine), 20 (2), 48-59. (in Russian with English summary). 
31. Kuznetsov, V.O., \& Shimko, G.A. (1990) The method of stage-by-stage extracts for the geochemical studies. Minsk: Nauka i tekhnika. (in Russian).

The article was received 17.04.2020 and was accepted after revision 24.07.2020

\section{Трофимчук Олександр Миколайович}

доктор технічних наук, професор, член-кореспондент НАН України, директор Інституту телекомунікацій і глобального інформаційного простору НАН України

Адреса робоча: 03186 Україна, м. Київ, Чоколівський бульвар, 13

ORCID ID 0000-0003-3782-4209e-mail: itelua@kv.ukrtel.net

\section{Курасва Ірина Володимирівна}

доктор геологічних наук, професор, завідувач відділу геохімії техногенних металів та аналітичної хімії Інституту геохімії, мінералогії та рудоутворення імені М.П. Семененка НАН України

Адреса робоча: 03680 Україна, м. Київ, проспект Академіка Палладіна, 34

ORCID ID 0000-0003-3113-7782 e-mail: ki4412674@gmail.com

\section{Азімов Олександр Тельманович}

доктор геологічних наук, старший науковий співробітник, провідний науковий співробітник Наукового центру аерокосмічних досліджень Землі Інституту геологічних наук НАН України

Адреса робоча: 01054 Україна, м. Київ, вул. О. Гончара, 55-б

ORCID ID 0000-0002-5210-3920 e-mail: azimov@ casre.kiev.ua

\section{Кармазиненко Сергій Петрович}

кандидат географічних наук, старший науковий співробітник Інституту географії НАН України

Адреса робоча: 01030 Україна, м. Київ, вул. Володимирська, 44

ORCID ID 0000-0001-8268-7851e-mail: karmazinenko78@gmail.com

\section{Злобіна Катерина Сергіївна}

кандидат геологічних наук, молодший науковий співробітник Інституту геохімії, мінералогії та рудоутворення імені М.П. Семененка НАН України

Адреса робоча: 03680 Україна, м. Київ, проспект Академіка Палладіна, 34

ORCID ID 0000-0001-8823-4642 e-mail: ecaterinka@ukr.net 